\title{
Review \\ Intelligent Packaging for Real-Time Monitoring of Food-Quality: Current and Future Developments
}

\author{
Andrea Dodero (D), Andrea Escher, Simone Bertucci, Maila Castellano (D) and Paola Lova *D \\ Department of Chemistry and Industrial Chemistry, Università degli Studi di Genova, Via Dodecanso 31, \\ 16146 Genova, Italy; andrea.dodero@edu.unige.it (A.D.); andrea.escher@edu.unige.it (A.E.); \\ simone.bertuccige@gmail.com (S.B.); maila.castellano@unige.it (M.C.) \\ * Correspondence: paola.lova@unige.it; Tel.: +39-0103356194
}

Citation: Dodero, A.; Escher, A.; Bertucci, S.; Castellano, M.; Lova, P. Intelligent Packaging for Real-Time Monitoring of Food-Quality: Current and Future Developments. Appl. Sci. 2021, 11, 3532. https://doi.org/ 10.3390/app11083532

Academic Editor: Sergio Torres-Giner

Received: 17 March 2021

Accepted: 13 April 2021

Published: 15 April 2021

Publisher's Note: MDPI stays neutral with regard to jurisdictional claims in published maps and institutional affiliations.

Copyright: (c) 2021 by the authors. Licensee MDPI, Basel, Switzerland. This article is an open access article distributed under the terms and conditions of the Creative Commons Attribution (CC BY) license (https:// creativecommons.org/licenses/by/ $4.0 /)$.
Abstract: Food packaging encompasses the topical role of preserving food, hence, extending the shelflife, while ensuring the highest quality and safety along the production chain as well as during storage. Intelligent food packaging further develops the functions of traditional packages by introducing the capability of continuously monitoring food quality during the whole chain to assess and reduce the insurgence of food-borne disease and food waste. To this purpose, several sensing systems based on different food quality indicators have been proposed in recent years, but commercial applications remain a challenge. This review provides a critical summary of responsive systems employed in the real-time monitoring of food quality and preservation state. First, food quality indicators are briefly presented, and subsequently, their exploitation to fabricate intelligent packaging based on responsive materials is discussed. Finally, current challenges and future trends are reviewed to highlight the importance of concentrating efforts on developing new functional solutions.

Keywords: food; intelligent packaging; food quality indicators; real-time monitoring; sensors

\section{Introduction}

According to the World Health Organization, every year, more than 600 million cases of illness are related to supplies of contaminated food and more than 400,000 people die due to foodborne contamination [1]. Indeed, even in highly developed countries, foodborne illnesses are still a serious cause of sickness and lead to several deaths per year [2]. Generally speaking, food quality can be identified by a broad number of factors including healthiness, consumer standards, nutritional values, and stability [3,4]. Hence, these factors represent a topical indicator to assess the effect of food on consumer health. In this sense, the food industry has recently started to pay great attention to evaluating food quality $[5,6]$. Nowadays, expiration dates are commonly employed for this purpose and to define product recall times. However, despite the existence of strict standard regulations, the complete lack of real-time monitoring of food preservation state is a threat to consumer health $[7,8]$. With these premises, it is not surprising that the worldwide food industry urges for the development of systems that can be easily incorporated into food packaging and are able to provide real-time quality insights. The efforts made in recent years have led to a promising emerging field, comprised of innovative packaging technologies showing the potential to substitute conventional materials [9-11].

Traditionally, common packaging technologies consist of the use of passive, inactive, and inert barriers with the function to prevent moisture, oxygen, and contaminants from becoming in contact with the food products. Hence, their main action is to maintain food quality over a certain period of time, protecting it against diverse physicochemical stresses [12,13]. On the contrary, innovative food packages may present one or multiple active functions able to play an active role in food preservation and quality indication. In this sense, the number of functionalities that can be embedded in smart packages is rapidly 
growing. These new materials promise to cover a topical role in improving food safety, enhancing food quality, and minimizing food waste.

Several terms such as "smart", "active", and "intelligent" are commonly employed to describe novel packaging technologies. Despite these terms being used interchangeably in the literature, they are representative of different concepts [14]. Specifically, intelligent packages do not directly act on food products, but only monitor their condition, whereas active packages have the role to increase the food shelf-life by acting on the environment surrounding the food. Remarkably, intelligent and active packaging may work in synergy, creating what is nowadays indicated as smart packaging $[10,15]$. Generally speaking, given the properties shown by actives packaging materials, these can be simply considered an extension of the traditional food packaging systems and are nowadays broadly employed in several commercial products $[16,17]$. Conversely, the purpose of intelligent packages is the real-time quality evaluation of food products and/or the surrounding environment through a variety of signals $[13,18-20]$. Specifically, diverse quality indicators (e.g., pH, humidity, temperature, specific chemicals, etc.) can be exploited for this purpose $[7,21-25]$. However, even though several food quality monitoring devices have been developed in the past and the number of scientific articles on the topic has been quickly increasing in the past decade, excluding temperature-based sensing systems (see Section 3.5), intelligent packages able to ensure real-time monitoring on a large commercial scale are still far from being achieved [26]. The main problems of such systems encompass the high cost, the requirement of sophisticated instrumentations, and the difficult integration in existing packaging materials. Thereby, as already pointed out by several reviews published in recent years, despite the fact that these sensing technologies allow for detecting food spoilage with high sensitivity, they are not yet suitable for industrial applications [27-29]. In this term, optical sensors have been increasingly investigated and show great potential for the food packaging sectors. Indeed, these systems are low-cost, do not require electronic connections or read-out devices, and are suitable for use by untrained operators, represented by the distribution chain operators and the consumers. Such sensors can be based on several working principles including colorimetric assay, fluorogenic receptors, photonic structures, and plasmonic particles. In all cases, one of the main advantages of these sensors is the response that is easy-to-read using the naked-eye due to the simple color variations.

With this in mind, this review aims to provide a concise but comprehensive summary of the recent developments concerning the real-time monitoring of food products via innovative packaging technologies mostly based on optical detection systems. Hence, we first briefly introduce the main indicators of food quality and how they can be exploited to perform real-time monitoring. Subsequently, we report a detailed description of the efforts made in developing "optical" intelligent packages that can be directly employed for monitoring food quality. Finally, a short summary of the current challenges and future perspectives is reported.

\section{Food Quality Indicators}

Specific indicators able to indicate the quality state of food products are usually connected to physical or chemical modifications that occur in a certain product, such as changes the in food consistency (e.g., thinning or thickening of sauces), in the food color (e.g., browning due to oxidation reactions), and in the food flavor and odor (e.g., rancidity due to $\mathrm{pH}$ variations) [30,31]. The detection of such indicators can effectively reduce the risks connected to the consumption of unsafe food, consequently limiting foodborne illnesses. Table 1 summarizes the main food quality and safety indicators and their applications in real-time monitoring, whereas a brief introduction of such indicators is presented in the following section. 
Table 1. Summary of the main food quality and safety indicators and their main applications in food packages.

\begin{tabular}{ccc}
\hline $\begin{array}{c}\text { Sensing } \\
\text { Indicator }\end{array}$ & $\begin{array}{c}\text { Working } \\
\text { Principle }\end{array}$ & $\begin{array}{c}\text { Main } \\
\text { Applications }\end{array}$ \\
\hline $\mathrm{O}_{2}$ & $\begin{array}{c}\text { Luminescence-based } \\
\text { Redox-based } \\
\text { Colorimetric assay-based }\end{array}$ & Modified atmosphere packages \\
\hline $\mathrm{CO}_{2}$ & $\begin{array}{c}\text { Luminescence-based } \\
\text { Colorimetric assay-based }\end{array}$ & Modified atmosphere packages \\
\hline Humidity & $\begin{array}{c}\text { Inductor and capacitor-based } \\
\text { Colorimetric assay-based } \\
\text { Photonic crystal-based }\end{array}$ & $\begin{array}{c}\text { Modified atmosphere packages } \\
\text { Dry food products }\end{array}$ \\
\hline pH & $\begin{array}{c}\text { Colorimetric assay-based } \\
\text { Electrochemical assay-based } \\
\text { Photonic crystal-based }\end{array}$ & Meat, fish, and dairy products \\
\hline Temperature & Colorimetric assay-based & Frozen food products \\
\hline Nitrogen & $\begin{array}{c}\text { Antibodies-based } \\
\text { Colorimetric assay-based }\end{array}$ & Meat and fish products \\
\hline
\end{tabular}

\subsection{Oxygen and Carbon Dioxide}

Regulating the contact between oxygen and carbon dioxide in the context of food is important to avoid degradation and proliferation of micro-organisms. Oxygen can, indeed, trigger browning and other oxidative processes in meat, fish, cheese, and pigments in a variety of fresh foods [32-34]. Conversely, carbon dioxide inhibits the growth of bacteria and fungi, owing to both its capability to establish an anaerobic environment and decrease the $\mathrm{pH}$ of the environment of food $[35,36]$. Therefore, controlling the amount of $\mathrm{O}_{2}$ and $\mathrm{CO}_{2}$ represents an important strategy to extend the shelf-life of food and several modified atmosphere packages have been developed for non-respiring food products (i.e., products in which the initial atmosphere composition must be controlled to ensure optimal preservation) $[37,38]$. As a consequence, monitoring any change in the gas concentration and/or composition may indicate the conservation state of food [39-41].

\subsection{Humidity}

Constant humidity values are essential for preserving the condition and texture of food. Indeed, low humidity values can dry the edibles, while an excess of moisture can provide the ideal environment to foster microbic and fungi growth [42,43]. Common packaging technologies are supposed to not be permeable to moisture [44-46]. As a matter of fact, the level of humidity inside food packages can undergo significant variations due to accidental breakage of the package as a consequence of improper manipulation and prolonged exposure to significant temperature fluctuations. Therefore, humidity is a key factor to be considered in food quality assessment as it can provide useful information as regards improper storage conditions.

\section{3. $p H$ Changes}

During food storage, certain types of both aerobic and anaerobic microorganisms can proliferate, generating organic acids (e.g., lactic acid and acetic acid) that can decrease the $\mathrm{pH}$ of food. Additionally, carbon dioxide, which is a product of microbial growth, may dissolve in food products and produce carbonic acid, which further decreases the $\mathrm{pH}$ value $[47,48]$. Hence, $\mathrm{pH}$-sensitive sensors have been widely explored to evaluate food freshness and safety [49-51]. 


\subsection{Temperature}

Temperature is another important indicator related to food spoilage, with high values and significant fluctuations with a strong impact on the shelf-life of refrigerated food $[14,52,53]$. Indeed, temperature rising can easily trigger microbial proliferation and subsequent product deterioration. Specifically, since temperature fluctuations may occur at any point in the distribution chain, real-time monitoring is essential for certain food products, such as fish, for which the temperature broadly affects the microbial activity rate.

\subsection{Nitrogen Related Compounds}

Animal-derived food products, such as meat, fish, and dairy, represent a class of consumables that are highly susceptible to the undesired proliferation of pathogenic microorganisms, which causes their rapid degradation and the creation of biogenic amines [54-56]. Generally speaking, the increase in the total volatile basic nitrogen (TVB-N) concentration is known to be an indicator of food spoilage and the formation of compounds that are hazardous to health, such as histamine, cadaverine, and putrescine [57-59]. Thus, TVB-N and related compounds are a promising figure of merit for the continuous assessment of the quality of fresh protein-based products.

\section{Methods for Real-Time Food Monitoring}

The European Commission has defined intelligent food packages as "materials and articles that monitor the condition of packaged food or the environment surrounding the food" [60]. Generally speaking, intelligent packaging can be explained as a combination of science and technology able to enhance the shelf-life, improve safety, guarantee the quality, and warn about any harmful changes occurring in the packages $[18,21,49,61-64]$. Specifically, intelligent packaging makes use of the internal or external package environment to monitor the food quality status $[13,19,65]$. A summary of the most common methods currently employed for the real-time monitoring of food samples based on the indicator nature is discussed in the following.

\section{1. $\mathrm{O}_{2}$ Detectors}

Modified atmosphere packages (MAPs) have been broadly employed to prolong the shelf-life of various edible products $[66,67]$. In a typical MAP, the product is sealed in a gas mixture where oxygen, nitrogen, and carbon dioxide concentrations are controlled. In this regard, different sensors able to monitor the concentration of oxygen within MAPs have been developed [39,40,68,69]. Luminescence-based indicator systems based on fluorogenic molecules embedded in a polymer film that is permeable to gas and/or ions, (e.g., silicon rubber, poly(vinyl chloride), etc.) modify their photoluminescence upon oxygen exposure. However, when photo-excited with environmental light sources, this kind of sensor lacks a response that is significantly discernible by the naked human eye, thereby requiring intense photo-excitation sources (e.g., light-emitting diodes or lasers) and apposite detectors [70-72]. Alternatively, colorimetric redox sensors exploiting simple reversible redox chemistry [73-76] and consisting of a redox dye (e.g., methylene blue) and a strong reducing agent (e.g., glucose in an alkaline environment) are able to change color upon small oxygen variations (i.e., $0.1 \%$ ). Figure 1 a schematizes the color variation achievable in a commercial system upon the presence of oxygen [77]. The sensor changes its color from pink to blue within a few hours upon oxygen exposure. Despite their high sensitivity and easy transduction, most of these sensors require to be stored and handled in anaerobic conditions, which considerably reduces their large-scale applicability in MAPs. Nevertheless, when in contact with high moisture environments typical of food packages, these redox dyes may be released from the water-insoluble polymer matrix in which they are embedded and diffuse into the packaging, hence posing health concerns. In this sense, the cation-binding capability of alginate, a polysaccharide extracted from brown algae and widely exploited in biomedical, pharmaceutical, wastewater remediation, and food applications [78-83], has been used to prevent dye leaching [84]. 
a

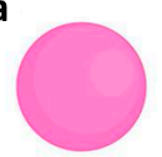

Oxygen free package $(0.1 \%)$ or less
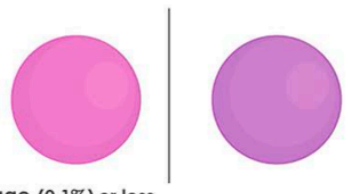
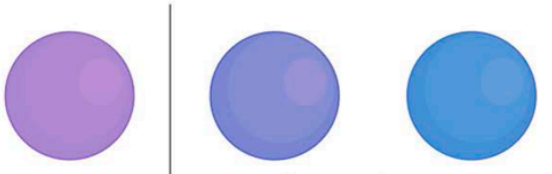

Oxygen is present $(0.5 \%)$ or more

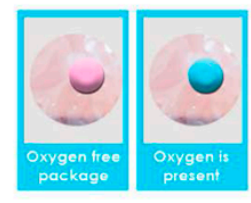

Oxygen free package

Oxygen is present

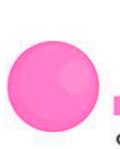

$2-3$ hours after oxygen level has reached Oxygen-free $\left(25^{\circ} \mathrm{C}\right)$

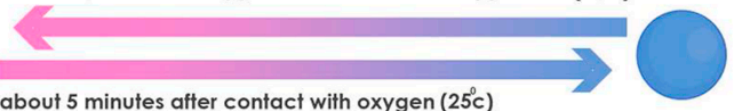

b
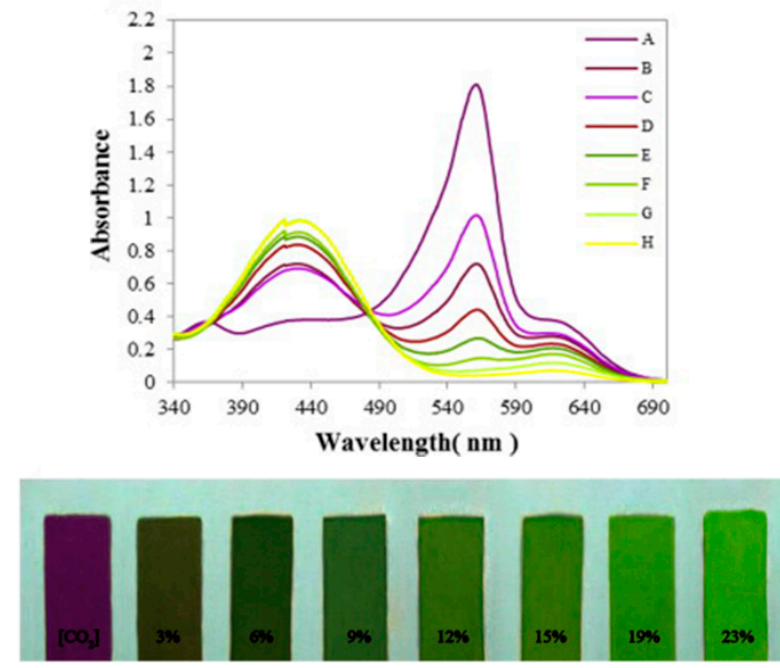

Figure 1. (a) $\mathrm{O}_{2}$ sensors based on a colorimetric redox dye. Reproduced with permission from [7]. Copyright (C) 2019 American Chemical Society. (b) Label color changes in response to $\mathrm{CO}_{2}$. Adapted with permission from [85]. Copyright (C 2014 Elsevier B.V. All rights reserved.

\section{2. $\mathrm{CO}_{2}$ Detectors}

Two main groups of optical sensors have been mainly reported for $\mathrm{CO}_{2}$ monitoring in food packages. The first group is based on luminescent dyes which modify their fluorescence upon $\mathrm{CO}_{2}$ exposure, while the second is based on colorimetric indicators sensitive to the $\mathrm{pH}$ changes induced by $\mathrm{CO}_{2}$ hydrolysis in the sensor matrix $[47,85-89]$. Luminescent dyes are characterized by performing extreme sensing capabilities, but they require sophisticated instruments, both for excitation and sensing, and are not suitable for consumer use. One of the first devices of this type was developed by embedding 8-hydroxypyrene-1,3,5-trisulfonic acid within a polymeric film, obtaining a response and a recovery of less than $10 \mathrm{~s}$ [90]. Such a system was further developed by first immobilizing the fluorophore molecule on a silica matrix [88] and then adding a dual fluorophore referencing system [47]. However, since the chemicals required for the sensor production are not food-grade, it is, hence, of fundamental importance that they do not become in contact with the products. To develop $\mathrm{CO}_{2}$ sensors with actual applicability in large-scale packages, recent efforts have been devoted to the exploitation of colorimetric indicators. These generally have a lower sensitivity with respect to luminescent dyes but are much cheaper, safer, and provide a response that is discernible by the human eye without the need for any instrumentation [47,91-93]. For example, the m-cresol purple dye has been broadly employed to fabricate colored polymer films sensible to protonation and deprotonation [94-98], as schematically shown in Figure 1b, which reports a colorimetric detector based on a mixture of bromothymol blue, bromocresol green and phenol red [85]. The absorbance spectrum of the mixture in a $\mathrm{CO}_{2}$-free environment (top panel of Figure 1a, 
purple line) shows a maximum in the green region, corresponding to a purple color, as depicted in the bottom panel of the same figure. Upon $\mathrm{CO}_{2}$ exposure, the previously mentioned peak is quenched and a second one arises in the blue and violet spectral regions. Thereby, such a variation allows the color of the system to visibly turn from purple to green upon $\mathrm{CO}_{2}$ exposure. Additionally, both a good shelf-life and functional design have been demonstrated by using food-grade formulations comprised of L-lysine, poly L-lysine, and anthocyanins [47].

\subsection{Specific Chemicals and $\mathrm{pH}$ Changes}

During food spoilage, several chemical modifications may occur in the packaging environment related to specific microorganism growth, especially for meat and fish products [55]. Thereby, as described below, different types of colorimetric assays exploiting chemical indicators have been vastly used to monitor food quality owing to their accuracy, simplicity, low cost, rapidity, and reliability [99-103]. As an example, polyaniline-based films embedded within the packaging lead to visible color changes in the presence of biogenic amines [104]. This sensor exploits the unique capability of polyaniline to change conductivity and color as a consequence of $\mathrm{pH}$ variation. The colorimetric assay has also been demonstrated by exploiting 16 different chemosensitive compounds that are able to detect several chemical species including trimethylamine, dimethylamine, cadaverine, and putrescine [105]. Remarkably, since food spoilage is diversified depending on both the sample type and world location, such a sensor acts as a universal system displaying great versatility in detecting a wide range of compound varieties [106-108]. Alternatively, electrochemical sensors, which are based on the redox reaction of a certain species on an electrode surface generating an electrical signal, have been broadly explored for the detection of volatile amine compounds during food deterioration, especially in the case of animal-derived products (i.e., meat and fish) [48,109-112]. In this regard, a wireless sensor was recently fabricated by using a hydrogel-coated $\mathrm{pH}$-electrode sensor sensible to the environmental amount of volatile amine with a detection limit of $0.001 \mathrm{mg} / \mathrm{L}$ [113]. These sensors have the main advantage of providing a rapid and highly sensitive response to food spoilage, while also providing information as regards the concentration of the analyte species. On the other hand, due to their greater sophistication with respect to colorimetric sensors, it is noteworthy that electrochemical sensors are much harder to implement in packaging systems. Additionally, several meat spoilage sensors have been developed by means of $\mathrm{pH}$-responsive materials directly incorporated within the packages $[114,115]$. Again, the simple optical determination of vapor diffusion in thin polymeric films has been demonstrated as being a useful tool for food monitoring applications [23], as shown in Figure 2. The detection system exploits the optical interference of a commercial clingwrap film (Figure 2a, red line). Upon exposure to different vapor phase analytes, the wrap increases its thickness, and its interference pattern is modified (Figure 2a, black line). Recording the dynamics of these variations (Figure $2 b$ ), it is possible to assess the diffusion coefficient of the diffusing species (Figure 2c, top panel) and relate the spectral shift of the interference pattern to the van der Waals volume of the analyte (Figure 2c, bottom panel). Yet, photonic crystals have also been shown to be able to act as indicators of food spoilage, owing to their capability to provide an easily discernible optical response to nitrogen-derived compounds [116-118]. 


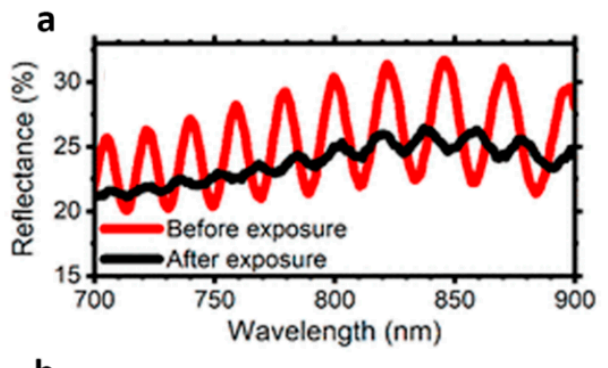

b

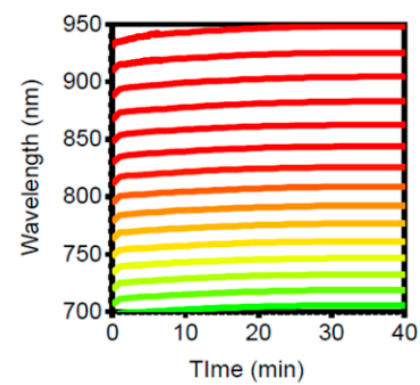

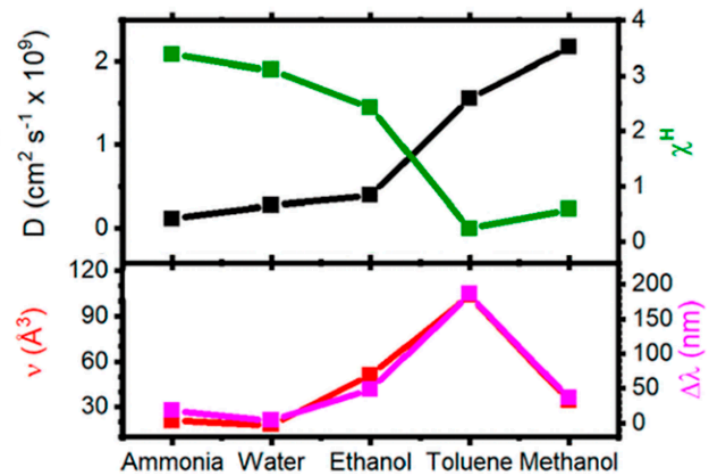

Figure 2. (a) Reflectance of a thin polyvinyl chloride (PVC) film before (red line) and after (black line) $\sim 5 \mathrm{~min}$ in toluene vapor. (b) Response of a thin PVC film to water with the spectral position of relative maxima during the exposure. (c) Diffusion coefficient $(D)$, Flory-Huggins parameter $\left(x^{\mathrm{H}}\right)$, and comparison $(v)$ between the van der Waals volume of the diffusing species and the spectral shift of the relative maximum. Adapted with permission from [23]. Copyright $\odot 2020$ American Chemical Society.

\subsection{Humidity Sensors}

Several humidity sensors have been explored in recent years for real-time packaging monitoring purposes [119-122]. As described in detail below, these sensors have the advantage of being simple and easily implemented in food packages. For instance, a low-cost wireless humidity sensor, which can be easily introduced inside packages, was developed using a planar inductor and capacitor fixed on a paper substrate [123]. Generally speaking, using a paper substrate ensures a cheap platform, high sensitivity, and a reasonable response time. Indeed, when the humidity within the packaging increases, this substrate adsorbs water, hence, modifying the capacitance of the capacitor [124,125]. Humidity sensors coupled with a radio frequency identification (RFID) tag have also been reported [126-129]. These usually consist of two planar inductor-capacitor resonators (Figure 3a), with one of them encoding the ID data and the other one working as the humidity sensor [126]. Figure $3 \mathrm{~b}$ reports the measured signal of a sensor unit at room temperature: a higher humidity value corresponds to a lower resonance frequency. Alternatively, RFID humidity sensors comprising of a printed spiral inductor working as an antenna can be developed [130]. However, humidity-based sensing materials based on photonic crystals have been widely investigated as a valid system for the real-time monitoring of food packaging owing to their high sensitivity, low cost, and high productivity rate [131-133]. For example, Figure $3 \mathrm{c}$ shows the red-shift of the photonic band-gap of a synthetic opal hydrogel. The opal consists of highly monodisperse polystyrene microspheres self-assembled on a glass substrate and infiltrated with a poly(acrylamide-co-acrylic acid) hydrogel network. By increasing the relative humidity (RH), the hydrogel swells, modifying the lattice periodicity and in turn, the optical response of the opal [134]. 


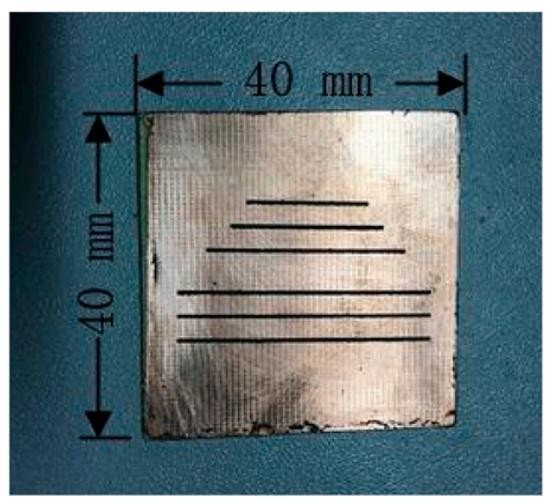

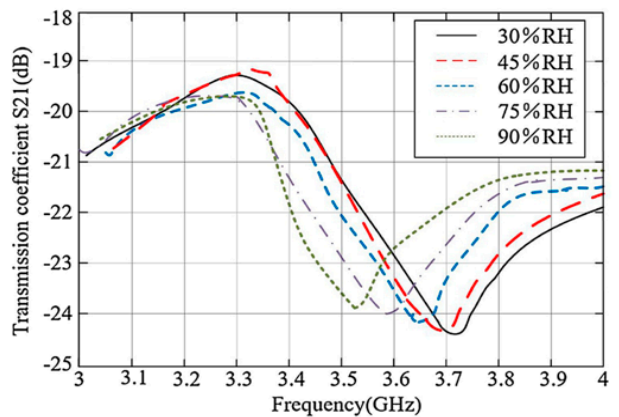

c

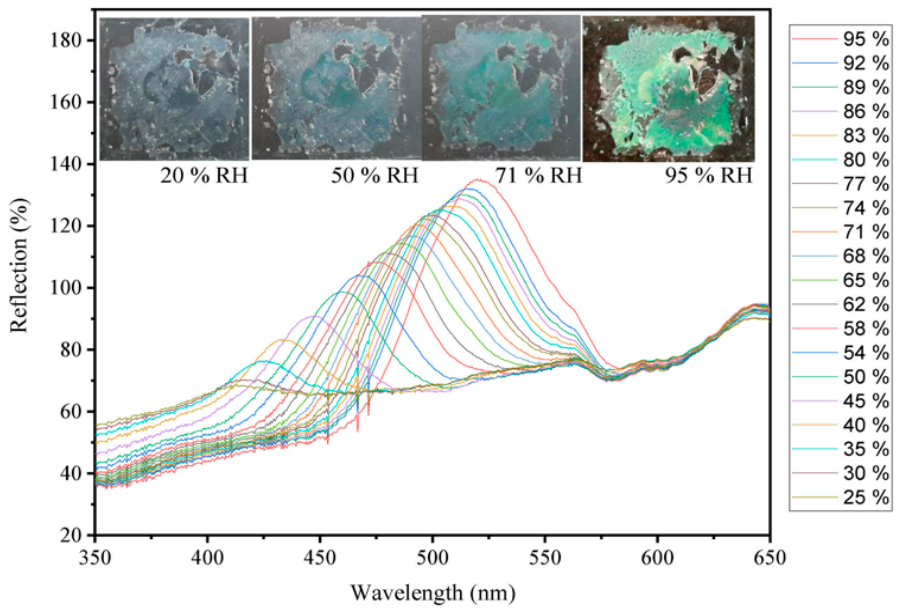

Figure 3. (a) Photo of a generic humidity-based sensor radio frequency identification (RFID) tag and (b) transmission coefficient S21 of the sensor unit at $25^{\circ} \mathrm{C}$. Reproduced with permission from [126]. Copyright (c) 2018 Elsevier B.V. All rights reserved. (c) Spectra shift of an opal hydrogel composite by increasing RH (\%). Reproduced with permission from [134]. Copyright @ 2020 Published by Elsevier Ltd.

Humidity sensors, such as those described above, find potential applications in dry food packages, which require the avoidance of any contact with moisture and maintaining a very low humidity level to avoid degradation. Due to their ease of fabrication and cheap cost, such systems are promising candidates for commercial applications on a large scale, however their long-term stability still needs to be optimized.

\subsection{Time-Temperature Sensors}

Sensors based on temperature detection consist of devices in direct contact with the food products [135-138]. As these variations typically result in significant mechanical, chemical, electrochemical, enzymatic, or microbiological changes in the food samples, temperature sensors are extremely useful in spoilage monitoring [139-144]. Time-temperature indicator (TTIs) systems can be divided into three main groups: critical temperature indicators, critical time-temperature indicators, and full history indicators [12]. In detail, critical temperature indicators can only provide information in regard to deterioration and changes in food organoleptic properties due to the occurrence of temperature dissimilarities with respect to a reference value for a certain time. Usually, this kind of sensor exploits irreversible but visible changes in the color of the indicator. For instance, Figure 4a shows a critical temperature sensing system based on an enzymatic reaction with a sensitive spot that changes color under thermal exposure (i.e., orange color indicates that the product has been compromised) [145]. Critical time-temperature indicators supply indications 
associated with the cumulative effect of time and temperature on product quality or safety when these have been exposed to a temperature above the reference one for a certain period. By way of example, Figure $4 \mathrm{~b}$ reports a commercially available critical TTIs system for the monitoring of frozen food products. A blue color appears in the viewing window if a breach of the threshold temperature has occurred. The duration of one or more breaches is shown by how far the blue color has progressed along with the time markers [146]. Finally, full history indicators continuously monitor the temperature changes to which a sample is subjected, with the data being recorded in terms of irreversible changes that explain food safety and quality to consumers. Generally speaking, temperature-based sensors are, nowadays, the only ones exploited in the food industry, owing to their relatively small size, low cost, and simplicity compared to other food monitoring devices [147-151].

a

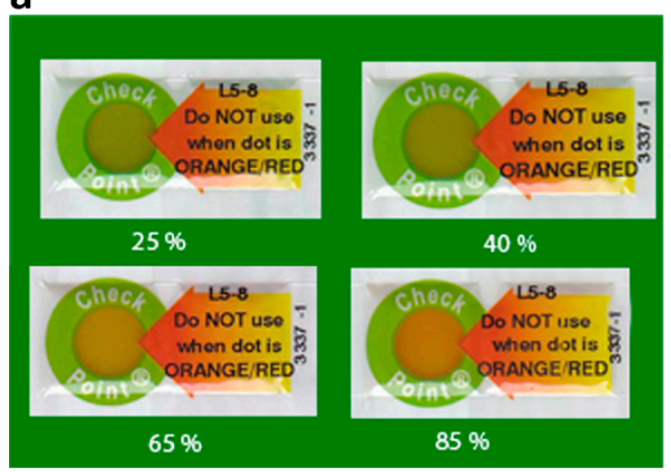

b

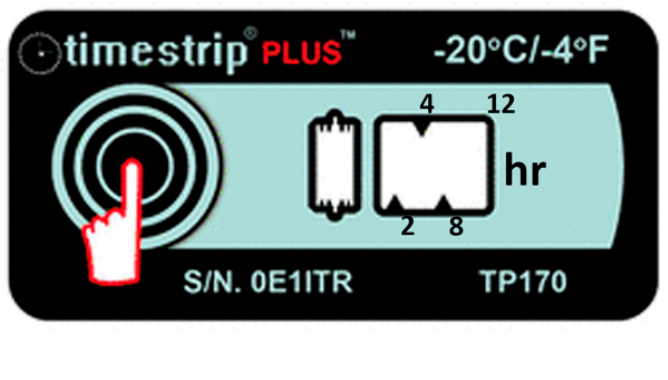

Figure 4. (a) Critical temperature sensing system based on an enzymatic reaction and capable of indicating if a product has been compromised. (b) Critical time-temperature sensing system that indicates how long a breach of the threshold temperature has occurred. Adapted with permission from [7]. Copyright (C) 2019 American Chemical Society.

\subsection{Biosensors for Bacteria Detection}

Among others, bacteria are one of the primary food contaminants associated with disease and death [152]. The growth of microorganisms in food may affect product quality in two different ways. On the one hand, non-pathogenic microorganisms normally present in the food supply chain can induce food spoilage and determine a quality issue. On the other hand, pathogens deriving from contamination at a certain point of the supply chain represent a serious health risk $[5,152,153]$. With these premises, it is not surprising that bacteria are an extremely important target in food safety monitoring. However, commonly employed approaches make use of expensive, time-consuming, and sophisticated analytical techniques that are not suitable for large-scale applications [153-156]. Accessibility problems have been solved via devices that do not require significant user intervention and that are not destructive [157]. For instance, the presence of microorganisms in various food packages has been detected via lateral-flow strip (LFTS) assays [158-160], in which gold colloidal nanoparticles labeled with antibodies directed against specific microorganisms are deposited on a chromatographic test strip as schematically shown in Figure 5a. A sample containing the bacterium is then inserted at one side of the strip via a proper solution. The solution runs along the strip until it encounters the functionalized particles with the specific antibodies that interact with the bacteria. In the test zone, a detection line bringing receptors for the bacterium-gold complex interacts with the latter and induces particle accumulation that gives rise to a colored line. At the same time, the essay also has a control line aimed at assessing the chromatographic process. This line brings a receptor that interacts with a second group of gold nanoparticles that are opportunely functionalized.

Another type of bacteria sensor has been fabricated by using portable microfluidic devices containing specific antibodies, which are able to respond to different bacteria and can be integrated with sensor chips [161-164]. For example, Figure 5b schematizes the working principle of a completely automated microfluidic-based electrochemical biosensor 
able to detect $E$. coli bacteria with high sensitivity (i.e., detection limit of $50 \mathrm{cfu} / \mathrm{mL}$ ) and specificity [164]. Specifically, such a biosensor relies on the enzymatic reaction between horseradish peroxidase (HRP) labeled E. coli antibodies and 3,3',5,5'-tetramethylbenzidine (TMB). Additionally, the detection of bacteria for intelligent food packaging applications via graphene flexible sheets operating as electrodes [165], via the aggregation of paramagnetic silica beads [166], or via laser speckle decorrelation (Figure 5c) $[167,168]$ has been demonstrated. Despite these sensor systems allowing for the real-time monitoring of microorganisms in packages and the fact that they may be suitable for large-scale usage, it is noteworthy that they still require sophisticated instruments.

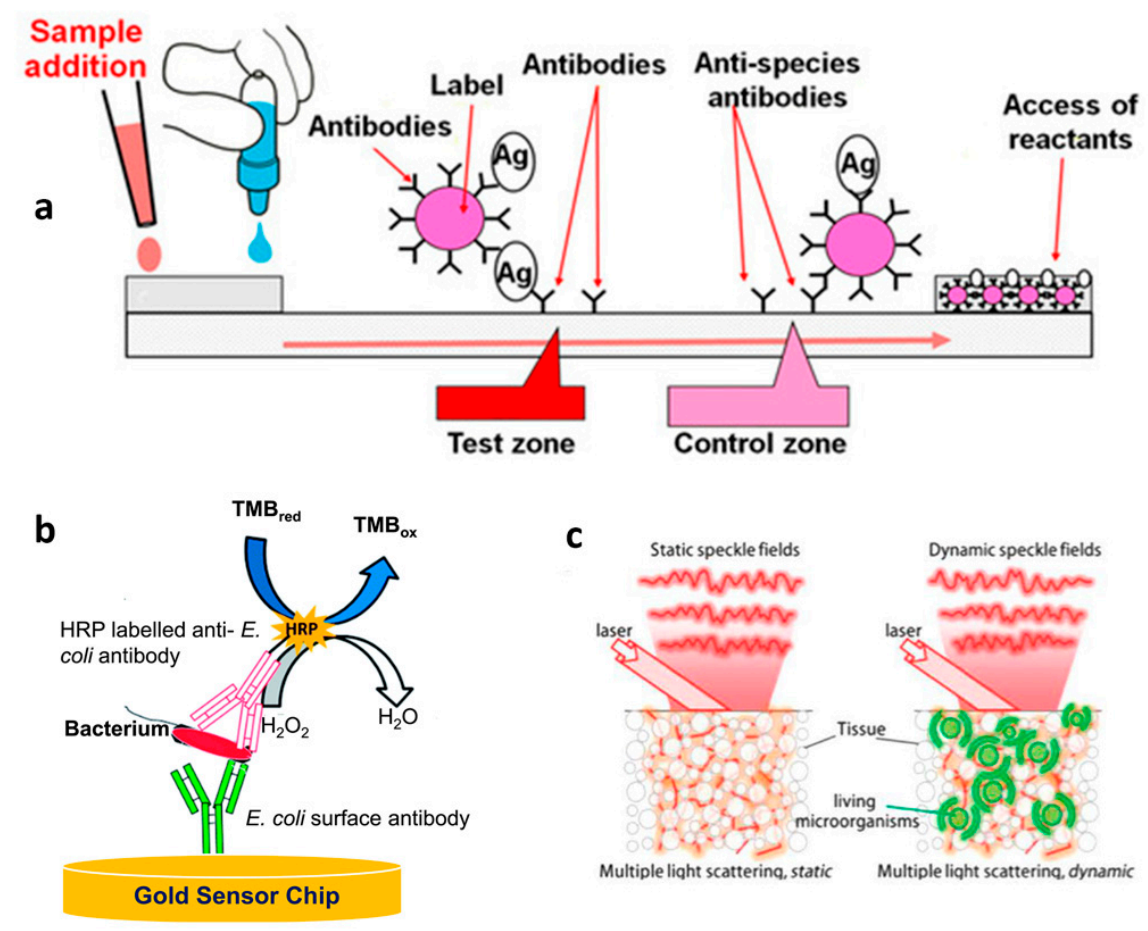

Figure 5. (a) Schematic of lateral-flow test strips (LFTS), where the development of a visible line in the testing zone indicates the presence of the target bacteria. Reproduced with permission from [169]. Copyright () 2019 by the authors. Licensee MDPI, Basel, Switzerland. (b) Microfluidic device based on a gold sensor chip for the real-time electrochemical detection of E. coli. Reproduced with permission from [164]. Copyright (C) 2017 Elsevier B.V. All rights reserved. (c) Working principle of laser speckle imaging used to evaluate the growth of bacteria. Reproduced with permission from [7]. Copyright (c) 2019 American Chemical Society.

To tackle the issues related to complex detection techniques or lack of on-site monitoring possibilities, photonic crystal-based sensors have started to assume a major role in microorganism detection for food packaging $[170,171]$. Figure $6 a, b$ reports a photograph and a schematic of a silica-titania multi-layered photonic crystal covered by a plasmonic Ag film. The system can selectively interact with the E. coli bacterium modifying its transmittance spectrum (Figure 6c) $[172,173]$. Devices based on photonic crystals and optical microcavities $[174,175]$ can be easily embedded in food packages, even though their large-scale fabrication has only been reported for polymer planar structures [176]. 

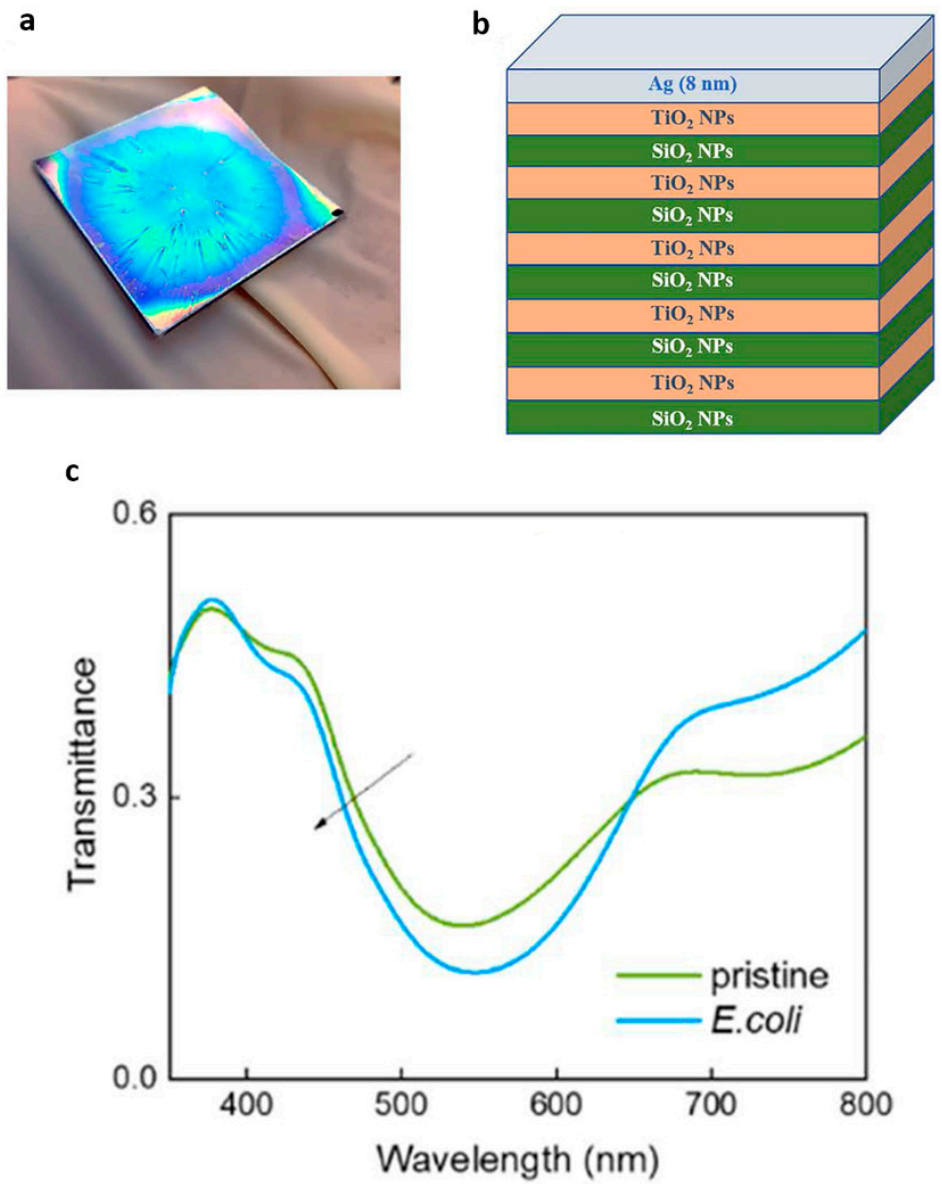

Figure 6. (a) Picture of a hybrid plasmonic-photonic crystal and (b) sketch of the multilayered structure. (c) Optical transmittance before (green) and after exposure to E. coli (blue line). Reproduced with permission from [172]. Copyright (C) 2019, American Chemical Society.

\section{Future Perspectives and Concluding Remarks}

Nowadays, the market for active, intelligent, and smart food packaging is rapidly increasing with more than USD 38 billion worth of packages being sold in 2020 and about USD 50 billion expected by 2026 [177]. However, such systems are still scarcely applied due to their high cost compared to traditional packaging materials and the limited possibility of integration within the existing packages [178-180]. In this sense, the recent developments in chemistry, microelectronics, materials science, engineering, biotechnology, and nanotechnology may help in the design and fabrication of efficient, novel packaging solutions suitable for large-scale applications. For instance, food quality optical detection systems based on colorimetric sensors display great potential to overcome the current challenges, including the high cost and the requirement of sophisticated instruments. Such systems may, indeed, provide a simple and easily readable indication concerning food quality over a long time period. Additionally, the sensitivity of such colorimetric devices and sensors may be even enhanced by integrating them with an RFID, aiming to achieve improved safety and quality, while reducing food waste and limiting costs [181-184]. Specifically, on one side, colorimetric systems allow for easy read-out by any kind of user, including the consumers. On the other, the continuous advances in printed electronics via the deposition of conductive inks on various substrates are expected to favor the integration of intelligent sensors in packaging materials [185,186]. Nevertheless, it is noteworthy that the lack of standardized and comprehensive toxicity evaluation methods, as well as the often limited stability of the so far developed sensors that could generate the migration of substances in the food products, has generated confused and frequently inconsistent data as far as health and safety concerns are considered. Thus, this poses a 
challenge in the large-scale fabrication and use of intelligent packages $[187,188]$. Hence, the development and validation of standardized tests concerning the safety of future intelligent packages represents one of the main issues to be addressed before their effective largescale usability. Moreover, it is critical to ensure that intelligent packaging is sustainable in terms of application, design, and production [189-192]. This is vital not only to improve the management of the food supply chain, but also to reduce global food waste and environmental pollution $[27,193]$. Specifically, the growing environmental burden related to petroleum-derived plastics imposes the enrichment of packaging products with ecofriendly features. However, to date, intelligent devices such as colorimetric and optical tags and especially RFDI and sensors are often not yet designed in respect of recyclability and/or sustainability mechanisms, since their main purpose is to improve food shelf-life by being as cheap and functional as possible. Hence, naturally occurring polymers based on renewable resources, such as cellulose and chitosan, may represents considerable areas of innovation and exciting opportunities for the inexpensive, safe, and sustainable fabrication of eco-friendly intelligent packaging materials.

In conclusion, this review critically discusses the most common optical approaches and emerging technologies for real-time food monitoring and addresses topics related to their future development for large-scale food packaging applications. These are usually based on different types of food quality indicators (i.e., $\mathrm{pH}, \mathrm{O}_{2}, \mathrm{CO}_{2}$, temperature, etc.) and can provide information for consumers as regards product safety.

Funding: This research has been founded by University of Genova (FRA 2020).

Institutional Review Board Statement: Not applicable.

Informed Consent Statement: Not applicable.

Data Availability Statement: Not applicable.

Conflicts of Interest: The authors declare no conflict of interest.

\section{References}

1. Food safety. Available online: https://www.who.int/news-room/fact-sheets/detail/food-safety (accessed on 16 February 2021).

2. Estimating the Burden of Foodborne Diseases. Available online: https://www.who.int/activities/estimating-the-burden-offoodborne-diseases (accessed on 5 March 2021).

3. Kotsanopoulos, K.V.; Arvanitoyannis, I.S. The Role of Auditing, Food Safety, and Food Quality Standards in the Food Industry: A Review. Compr. Rev. Food Sci. Food Saf. 2017, 16, 760-775. [CrossRef] [PubMed]

4. Zhou, L.; Zhang, C.; Liu, F.; Qiu, Z.; He, Y. Application of Deep Learning in Food: A Review. Compr. Rev. Food Sci. Food Saf. 2019, 18, 1793-1811. [CrossRef] [PubMed]

5. Ali, M.H.; Zhan, Y.; Alam, S.S.; Tse, Y.K.; Tan, K.H. Food supply chain integrity: The need to go beyond certification. Ind. Manag. Data Syst. 2017, 117, 1589-1611. [CrossRef]

6. Callao, M.P.; Ruisánchez, I. An overview of multivariate qualitative methods for food fraud detection. Food Control 2018, 86, 283-293. [CrossRef]

7. Yousefi, H.; Su, H.M.; Imani, S.M.; Alkhaldi, K.; Filipe, C.D.; Didar, T.F. Intelligent Food Packaging: A Review of Smart Sensing Technologies for Monitoring Food Quality. ACS Sens. 2019, 4, 808-821. [CrossRef]

8. Corradini, M.G. Shelf Life of Food Products: From Open Labeling to Real-Time Measurements. Annu. Rev. Food Sci. Technol. 2018, 9, 251-269. [CrossRef] [PubMed]

9. Schaefer, D.; Cheung, W.M. Smart Packaging: Opportunities and Challenges. Procedia CIRP 2018, 72, 1022-1027. [CrossRef]

10. Chen, S.; Brahma, S.; Mackay, J.; Cao, C.; Aliakbarian, B. The role of smart packaging system in food supply chain. J. Food Sci. 2020, 85, 517-525. [CrossRef] [PubMed]

11. Ahmed, I.; Lin, H.; Zou, L.; Li, Z.; Brody, A.L.; Qazi, I.M.; Lv, L.; Pavase, T.R.; Khan, M.U.; Khan, S.; et al. An overview of smart packaging technologies for monitoring safety and quality of meat and meat products. Packag. Technol. Sci. 2018, 31, 449-471. [CrossRef]

12. Han, J.-W.W.; Ruiz-Garcia, L.; Qian, J.-P.P.; Yang, X.-T.T. Food Packaging: A Comprehensive Review and Future Trends. Compr. Rev. Food Sci. Food Saf. 2018, 17, 860-877. [CrossRef]

13. Kalpana, S.; Priyadarshini, S.R.; Maria Leena, M.; Moses, J.A.; Anandharamakrishnan, C. Intelligent packaging: Trends and applications in food systems. Trends Food Sci. Technol. 2019, 93, 145-157. [CrossRef]

14. Dobrucka, R.; Przekop, R. New perspectives in active and intelligent food packaging. J. Food Process. Preserv. 2019, 43, e14194. [CrossRef] 
15. Lydekaityte, J.; Tambo, T. Smart packaging: Definitions, models and packaging as an intermediator between digital and physical product management. Int. Rev. Retail. Distrib. Consum. Res. 2020, 30, 377-410. [CrossRef]

16. Yildirim, S.; Röcker, B.; Pettersen, M.K.; Nilsen-Nygaard, J.; Ayhan, Z.; Rutkaite, R.; Radusin, T.; Suminska, P.; Marcos, B.; Coma, V. Active Packaging Applications for Food. Compr. Rev. Food Sci. Food Saf. 2018, 17, 165-199. [CrossRef] [PubMed]

17. Vilela, C.; Kurek, M.; Hayouka, Z.; Röcker, B.; Yildirim, S.; Antunes, M.D.C.; Nilsen-Nygaard, J.; Pettersen, M.K.; Freire, C.S.R. A concise guide to active agents for active food packaging. Trends Food Sci. Technol. 2018, 80, 212-222. [CrossRef]

18. Poyatos-Racionero, E.; Ros-Lis, J.V.; Vivancos, J.L.; Martínez-Máñez, R. Recent advances on intelligent packaging as tools to reduce food waste. J. Clean. Prod. 2018, 172, 3398-3409. [CrossRef]

19. Müller, P.; Schmid, M. Intelligent Packaging in the Food Sector: A Brief Overview. Foods 2019, 8, 16. [CrossRef]

20. Lova, P.; Soci, C. Black GaAs: Gold-Assisted Chemical Etching for Light Trapping and Photon Recycling. Micromachines 2020, 11, 573. [CrossRef]

21. Sohail, M.; Sun, D.-W.; Zhu, Z. Recent developments in intelligent packaging for enhancing food quality and safety. Crit. Rev. Food Sci. Nutr. 2018, 58, 2650-2662. [CrossRef]

22. Megahd, H.; Oldani, C.; Radice, S.; Lanfranchi, A.; Patrini, M.; Lova, P.; Comoretto, D. Aquivion-Poly (N-vinylcarbazole) Holistic Flory-Huggins Photonic Vapor Sensors. Adv. Opt. Mater. 2021, 9, 2002006. [CrossRef]

23. Lova, P.; Megahd, H.; Comoretto, D. Thin Polymer Films: Simple Optical Determination of Molecular Diffusion Coefficients. ACS Appl. Polym. Mater. 2020, 2, 563-568. [CrossRef]

24. Lova, P.; Manfredi, G.; Bastianini, C.; Mennucci, C.; Buatier De Mongeot, F.; Servida, A.; Comoretto, D. Flory-Huggins Photonic Sensors for the Optical Assessment of Molecular Diffusion Coefficients in Polymers. ACS Appl. Mater. Interfaces 2019, 11, 16872-16880. [CrossRef] [PubMed]

25. Yin, J.; Migas, D.B.; Panahandeh-Fard, M.; Chen, S.; Wang, Z.; Lova, P.; Soci, C. Charge redistribution at GaAs/P3HT heterointerfaces with different surface polarity. J. Phys. Chem. Lett. 2013, 4, 3303-3309. [CrossRef]

26. Jeya Jeevahan, J.; Chandrasekaran, M.; Venkatesan, S.P.; Sriram, V.; Britto Joseph, G.; Mageshwaran, G.; Durairaj, R.B. Scaling up difficulties and commercial aspects of edible films for food packaging: A review. Trends Food Sci. Technol. 2020, 100, 210-222. [CrossRef]

27. Liegeard, J.; Manning, L. Use of intelligent applications to reduce household food waste. Crit. Rev. Food Sci. Nutr. 2020, 60, 1048-1061. [CrossRef] [PubMed]

28. Moustafa, H.; Youssef, A.M.; Darwish, N.A.; Abou-Kandil, A.I. Eco-friendly polymer composites for green packaging: Future vision and challenges. Compos. Part B Eng. 2019, 172, 16-25. [CrossRef]

29. Janjarasskul, T.; Suppakul, P. Active and intelligent packaging: The indication of quality and safety. Crit. Rev. Food Sci. Nutr. 2018, 58, 808-831. [CrossRef]

30. Lozano, M.G.; García, Y.P.; Gonzalez, J.A.S.; Bañuelos, C.V.O.; Escareño, M.P.L.; Balagurusamy, N. Biosensors for food quality and safety monitoring: Fundamentals and applications. In Enzymes in Food Biotechnology: Production, Applications, and Future Prospects, Elsevier: Amsterdam, The Netherlands, 2018; pp. 691-709, ISBN 9780128132807.

31. Kuswandi, B.; Jumina. Active and intelligent packaging, safety, and quality controls. In Fresh-Cut Fruits and Vegetables: Technologies and Mechanisms for Safety Control; Elsevier Inc.: Amsterdam, The Netherlands, 2019; pp. 243-294, ISBN 9780128161845.

32. Nooshkam, M.; Varidi, M.; Bashash, M. The Maillard reaction products as food-born antioxidant and antibrowning agents in model and real food systems. Food Chem. 2019, 275, 644-660. [CrossRef] [PubMed]

33. Hellwig, M. Analysis of Protein Oxidation in Food and Feed Products. J. Agric. Food Chem. 2020, 68, 12870-12885. [CrossRef]

34. Hu, K.; Huyan, Z.; Ding, S.; Dong, Y.; Yu, X. Investigation on food packaging polymers: Effects on vegetable oil oxidation. Food Chem. 2020, 315, 126299. [CrossRef] [PubMed]

35. Wang, W.; Rao, L.; Wu, X.; Wang, Y.; Zhao, L.; Liao, X. Supercritical Carbon Dioxide Applications in Food Processing. Food Eng. Rev. 2020, 1, 3. [CrossRef]

36. Silva, E.K.; Guimarães, J.T.; Costa, A.L.R.; Cruz, A.G.; Meireles, M.A.A. Non-thermal processing of inulin-enriched soursop whey beverage using supercritical carbon dioxide technology. J. Supercrit. Fluids 2019, 154, 104635. [CrossRef]

37. Wilson, M.D.; Stanley, R.A.; Eyles, A.; Ross, T. Innovative processes and technologies for modified atmosphere packaging of fresh and fresh-cut fruits and vegetables. Crit. Rev. Food Sci. Nutr. 2019, 59, 411-422. [CrossRef]

38. Mohi Alden, K.; Omid, M.; Rajabipour, A.; Tajeddin, B.; Soltani Firouz, M. Quality and shelf-life prediction of cauliflower under modified atmosphere packaging by using artificial neural networks and image processing. Comput. Electron. Agric. 2019, 163, 104861. [CrossRef]

39. Zhu, R.; Desroches, M.; Yoon, B.; Swager, T.M. Wireless oxygen sensors enabled by Fe(II)-polymer wrapped carbon nanotubes. ACS Sens. 2017, 2, 1044-1050. [CrossRef]

40. Kelly, C.; Yusufu, D.; Okkelman, I.; Banerjee, S.; Kerry, J.P.; Mills, A.; Papkovsky, D.B. Extruded phosphorescence based oxygen sensors for large-scale packaging applications. Sens. Actuators B Chem. 2020, 304, 127357. [CrossRef]

41. Jalali, A.; Seiiedlou, S.; Linke, M.; Mahajan, P. A comprehensive simulation program for modified atmosphere and humidity packaging (MAHP) of fresh fruits and vegetables. J. Food Eng. 2017, 206, 88-97. [CrossRef]

42. Batista, R.A.; Espitia, P.J.P.; de Quintans, J.S.S.; Freitas, M.M.; Cerqueira, M.Â.; Teixeira, J.A.; Cardoso, J.C. Hydrogel as an alternative structure for food packaging systems. Carbohydr. Polym. 2019, 205, 106-116. [CrossRef] 
43. Jalali, A.; Rux, G.; Linke, M.; Geyer, M.; Pant, A.; Saengerlaub, S.; Mahajan, P. Application of humidity absorbing trays to fresh produce packaging: Mathematical modeling and experimental validation. J. Food Eng. 2019, 244, 115-125. [CrossRef]

44. Wang, F.; Hu, Q.; Mugambi Mariga, A.; Cao, C.; Yang, W. Effect of nano packaging on preservation quality of Nanjing 9108 rice variety at high temperature and humidity. Food Chem. 2018, 239, 23-31. [CrossRef]

45. Opara, U.L.; Caleb, O.J.; Belay, Z.A. Modified atmosphere packaging for food preservation. In Food Quality and Shelf Life; Elsevie: Amsterdam, The Netherlands, 2019; pp. 235-259.

46. Bai, J.; Baldwin, E.; Tsantili, E.; Plotto, A.; Sun, X.; Wang, L.; Kafkaletou, M.; Wang, Z.; Narciso, J.; Zhao, W.; et al. Modified humidity clamshells to reduce moisture loss and extend storage life of small fruits $\star$. Food Packag. Shelf Life 2019, $22,100376$. [CrossRef]

47. Saliu, F.; Della Pergola, R. Carbon dioxide colorimetric indicators for food packaging application: Applicability of anthocyanin and poly-lysine mixtures. Sens. Actuators B Chem. 2018, 258, 1117-1124. [CrossRef]

48. Zhai, X.; Li, Z.; Zhang, J.; Shi, J.; Zou, X.; Huang, X.; Zhang, D.; Sun, Y.; Yang, Z.; Holmes, M.; et al. Natural Biomaterial-Based Edible and pH-Sensitive Films Combined with Electrochemical Writing for Intelligent Food Packaging. J. Agric. Food Chem. 2018, 66, 12836-12846. [CrossRef]

49. Balbinot-Alfaro, E.; Craveiro, D.V.; Lima, K.O.; Costa, H.L.G.; Lopes, D.R.; Prentice, C. Intelligent Packaging with pH Indicator Potential. Food Eng. Rev. 2019, 11, 235-244. [CrossRef]

50. Alizadeh-Sani, M.; Mohammadian, E.; Rhim, J.W.; Jafari, S.M. pH-sensitive (halochromic) smart packaging films based on natural food colorants for the monitoring of food quality and safety. Trends Food Sci. Technol. 2020, 105, 93-144. [CrossRef]

51. Kuswandi, B.; Asih, N.P.N.; Pratoko, D.K.; Kristiningrum, N.; Moradi, M. Edible pH sensor based on immobilized red cabbage anthocyanins into bacterial cellulose membrane for intelligent food packaging. Packag. Technol. Sci. 2020, 33, 321-332. [CrossRef]

52. Tsang, Y.P.; Choy, K.L.; Wu, C.H.; Ho, G.T.S.; Lam, H.Y.; Tang, V. An intelligent model for assuring food quality in managing a multi-temperature food distribution centre. Food Control 2018, 90, 81-97. [CrossRef]

53. Singh, S.; Gaikwad, K.K.; Lee, M.; Lee, Y.S. Temperature sensitive smart packaging for monitoring the shelf life of fresh beef. J. Food Eng. 2018, 234, 41-49. [CrossRef]

54. Bekhit, A.E.D.A.; Holman, B.W.B.; Giteru, S.G.; Hopkins, D.L. Total volatile basic nitrogen (TVB-N) and its role in meat spoilage: A review. Trends Food Sci. Technol. 2021, 109, 280-302. [CrossRef]

55. Comi, G. Spoilage of Meat and Fish. In The Microbiological Quality of Food: Foodborne Spoilers; Elsevier Inc.: Amsterdam, The Netherlands, 2017; pp. 179-210, ISBN 9780081005033.

56. Liu, B.; Gurr, P.A.; Qiao, G.G. Irreversible Spoilage Sensors for Protein-Based Food. ACS Sens. 2020, 5, 2903-2908. [CrossRef]

57. Schaude, C.; Meindl, C.; Fröhlich, E.; Attard, J.; Mohr, G.J. Developing a sensor layer for the optical detection of amines during food spoilage. Talanta 2017, 170, 481-487. [CrossRef] [PubMed]

58. Draz, M.E.; Darwish, H.W.; Darwish, I.A.; Saad, A.S. Solid-state potentiometric sensor for the rapid assay of the biologically active biogenic amine (tyramine) as a marker of food spoilage. Food Chem. 2021, 346, 128911. [CrossRef]

59. Torre, R.; Costa-Rama, E.; Nouws, H.P.A.; Delerue-Matos, C. Screen-Printed Electrode-Based Sensors for Food Spoilage Control: Bacteria and Biogenic Amines Detection. Biosensors 2020, 10, 139. [CrossRef] [PubMed]

60. EUR-Lex-32009R0450-EN-EUR-Lex. Available online: https://eur-lex.europa.eu/legal-content/EN/ALL/?uri=CELEX\%3A3 2009R0450 (accessed on 16 February 2021).

61. Ghoshal, G. Recent Trends in Active, Smart, and Intelligent Packaging for Food Products. In Food Packaging and Preservation; Elsevier: Amsterdam, The Netherlands, 2018; pp. 343-374.

62. Mirza Alizadeh, A.; Masoomian, M.; Shakooie, M.; Zabihzadeh Khajavi, M.; Farhoodi, M. Trends and applications of intelligent packaging in dairy products: A review. Crit. Rev. Food Sci. Nutr. 2020, 1-15. [CrossRef]

63. Gregor-Svetec, D. Intelligent packaging. In Nanomaterials for Food Packaging: Materials, Processing Technologies, and Safety Issues; Elsevier: Amsterdam, The Netherlands, 2018; pp. 203-247, ISBN 9780323512718.

64. Wang, L.; Wu, Z.; Cao, C. Technologies and Fabrication of Intelligent Packaging for Perishable Products. Appl. Sci. 2019, 9, 4858. [CrossRef]

65. Megahd, H.; Lova, P.; Comoretto, D. Universal Design Rules for Flory-Huggins Polymer Photonic Vapor Sensors. Adv. Funct. Mater. 2021, 31, 2009626. [CrossRef]

66. Oliveira, M.; Abadias, M.; Usall, J.; Torres, R.; Teixidó, N.; Viñas, I. Application of modified atmosphere packaging as a safety approach to fresh-cut fruits and vegetables-A review. Trends Food Sci. Technol. 2015, 46, 13-26. [CrossRef]

67. Zhang, M.; Meng, X.; Bhandari, B.; Fang, Z.; Chen, H. Recent Application of Modified Atmosphere Packaging (MAP) in Fresh and Fresh-Cut Foods. Food Rev. Int. 2015, 31, 172-193. [CrossRef]

68. Mills, A. Oxygen indicators and intelligent inks for packaging food. Chem. Soc. Rev. 2005, 34, 1003-1011. [CrossRef] [PubMed]

69. Kelly, C.; Cruz-Romero, M.; Kerry, J.; Papkovsky, D. Stability and Safety Assessment of Phosphorescent Oxygen Sensors for Use in Food Packaging Applications. Chemosensors 2018, 6, 38. [CrossRef]

70. Wolfbeis, O.S. Luminescent sensing and imaging of oxygen: Fierce competition to the Clark electrode. BioEssays 2015, 37, 921-928. [CrossRef]

71. Zhao, H.; Zang, L.; Wang, L.; Qin, F.; Zhang, Z.; Cao, W. Luminescence ratiometric oxygen sensor based on gadolinium labeled porphyrin and filter paper. Sens. Actuators B Chem. 2015, 215, 405-411. [CrossRef] 
72. Urriza-Arsuaga, I.; Ielasi, G.; Bedoya, M.; Orellana, G. Luminescence-Based Sensors for Bioprocess Applications; Springer: Cham, Switzerland, 2019; pp. 1-38.

73. Şen, F.B.; Bener, M.; Bekdeşer, B.; Apak, R. Redox-based colorimetric sensing of $\mathrm{H}_{2} \mathrm{O}_{2}$ after removal of antioxidants with ABTS radical oxidation. Spectrochim. Acta Part A Mol. Biomol. Spectrosc. 2021, 248, 119266. [CrossRef]

74. Imran, M.; Yousaf, A.B.; Zhou, X.; Liang, K.; Jiang, Y.F.; Xu, A.W. Oxygen-Deficient $\mathrm{TiO}_{2^{-}} \mathrm{X} /$ Methylene Blue Colloids: Highly Efficient Photoreversible Intelligent Ink. Langmuir 2016, 32, 8980-8987. [CrossRef]

75. Zhong, Y.; Shahidi, F. Methods for the assessment of antioxidant activity in foods. In Handbook of Antioxidants for Food Preservation; Elsevier Inc.: Amsterdam, The Netherlands, 2015; pp. 287-333, ISBN 9781782420972.

76. Silva-Pereira, M.C.; Teixeira, J.A.; Pereira-Júnior, V.A.; Stefani, R. Chitosan/corn starch blend films with extract from Brassica oleraceae (red cabbage) as a visual indicator of fish deterioration. LWT 2015, 61, 258-262. [CrossRef]

77. AGELESS EYE, Oxygen Indicator I Products I Mitsubishi Gas Chemical Company, Inc. Available online: https:/ /www.mgc.co.jp/ eng/products/sc/ageless-eye.html (accessed on 5 March 2021).

78. Dodero, A.; Lova, P.; Vicini, S.; Castellano, M.; Comoretto, D. Sodium alginate cross-linkable planar $1 \mathrm{~d}$ photonic crystals as a promising tool for $\mathrm{Pb} 2+$ detection in water. Chemosensors 2020, 8, 37. [CrossRef]

79. Dodero, A.; Vicini, S.; Lova, P.; Alloisio, M.; Castellano, M. Nanocomposite alginate-based electrospun membranes as novel adsorbent systems. Int. J. Biol. Macromol. 2020, 165, 1939-1948. [CrossRef]

80. Dodero, A.; Vicini, S.; Alloisio, M.; Castellano, M. Rheological properties of sodium alginate solutions in the presence of added salt: An application of Kulicke equation. Rheol. Acta 2020, 59. [CrossRef]

81. Dodero, A.; Alloisio, M.; Castellano, M.; Vicini, S. Multilayer Alginate-Polycaprolactone Electrospun Membranes as Skin Wound Patches with Drug Delivery Abilities. ACS Appl. Mater. Interfaces 2020, 12, 31162-31171. [CrossRef] [PubMed]

82. Dodero, A.; Vicini, S.; Castellano, M. Depolymerization of sodium alginate in saline solutions via ultrasonic treatments: A rheological characterization. Food Hydrocoll. 2020, 109, 106128. [CrossRef]

83. Dodero, A.; Donati, I.; Scarfi, S.; Mirata, S.; Alberti, S.; Lova, P.; Comoretto, D.; Alloisio, M.; Vicini, S.; Castellano, M. Effect of sodium alginate molecular structure on electrospun membrane cell adhesion. Mater. Sci. Eng. C 2021, 124, 112067. [CrossRef]

84. Vu, C.H.T.; Won, K. Novel water-resistant UV-activated oxygen indicator for intelligent food packaging. Food Chem. 2013, 140, 52-56. [CrossRef]

85. Rukchon, C.; Nopwinyuwong, A.; Trevanich, S.; Jinkarn, T.; Suppakul, P. Development of a food spoilage indicator for monitoring freshness of skinless chicken breast. Talanta 2014, 130, 547-554. [CrossRef] [PubMed]

86. Jung, J.; Puligundla, P.; Ko, S. Proof-of-concept study of chitosan-based carbon dioxide indicator for food packaging applications. Food Chem. 2012, 135, 2170-2174. [CrossRef] [PubMed]

87. Nopwinyuwong, A.; Trevanich, S.; Suppakul, P. Development of a novel colorimetric indicator label for monitoring freshness of intermediate-moisture dessert spoilage. Talanta 2010, 81, 1126-1132. [CrossRef] [PubMed]

88. Von Bültzingslöwen, C.; McEvoy, A.K.; McDonagh, C.; MacCraith, B.D.; Klimant, I.; Krause, C.; Wolfbeis, O.S. Sol-gel based optical carbon dioxide sensor employing dual luminophore referencing for application in food packaging technology. Analyst 2002, 127, 1478-1483. [CrossRef] [PubMed]

89. Wang, J.; Wen, Z.; Yang, B.; Yang, X. Optical carbon dioxide sensor based on fluorescent capillary array. Results Phys. 2017, 7, 323-326. [CrossRef]

90. Mills, A.; Chang, Q. Fluorescence plastic thin-film sensor for carbon dioxide. Analyst 1993, 118, 839-843. [CrossRef]

91. Bibi, F.; Guillaume, C.; Gontard, N.; Sorli, B. Wheat gluten, a bio-polymer to monitor carbon dioxide in food packaging: Electric and dielectric characterization. Sens. Actuators B Chem. 2017, 250, 76-84. [CrossRef]

92. Chocarro-Ruiz, B.; Pérez-Carvajal, J.; Avci, C.; Calvo-Lozano, O.; Alonso, M.I.; Maspoch, D.; Lechuga, L.M. A CO 2 optical sensor based on self-assembled metal-organic framework nanoparticles. J. Mater. Chem. A 2018, 6, 13171-13177. [CrossRef]

93. Lyu, J.S.; Choi, I.; Hwang, K.S.; Lee, J.Y.; Seo, J.; Kim, S.Y.; Han, J. Development of a BTB-/TBA+ ion-paired dye-based CO 2 indicator and its application in a multilayered intelligent packaging system. Sens. Actuators B Chem. 2019, 282, 359-365. [CrossRef]

94. Zou, X.; Wang, Y.; Liu, W.; Chen, L. M-Cresol purple functionalized surface enhanced Raman scattering paper chips for highly sensitive detection of $\mathrm{pH}$ in the neutral $\mathrm{pH}$ range. Analyst 2017, 142, 2333-2337. [CrossRef]

95. Zhu, M.; Kari, N.; Yan, Y.; Yimit, A. The fabrication and gas sensing application of a fast-responding m-CP-PVP composite film/potassium ion-exchanged glass optical waveguide. Anal. Methods 2017, 9, 5494-5501. [CrossRef]

96. Magnaghi, L.R.; Capone, F.; Zanoni, C.; Alberti, G.; Quadrelli, P.; Biesuz, R. Colorimetric Sensor Array for Monitoring, Modelling and Comparing Spoilage Processes of Different Meat and Fish Foods. Foods 2020, 9, 684. [CrossRef]

97. Xiao-wei, H.; Xiao-bo, Z.; Ji-yong, S.; Zhi-hua, L.; Jie-wen, Z. Colorimetric sensor arrays based on chemo-responsive dyes for food odor visualization. Trends Food Sci. Technol. 2018, 81, 90-107. [CrossRef]

98. Mills, A. Optical Sensors for Carbon Dioxide and Their Applications. In Sensors for Environment, Health and Security; Springer Netherlands: Dordrecht, The Netherlands, 2009; pp. 347-370.

99. Siripongpreda, T.; Siralertmukul, K.; Rodthongkum, N. Colorimetric sensor and LDI-MS detection of biogenic amines in food spoilage based on porous PLA and graphene oxide. Food Chem. 2020, 329, 127165. [CrossRef] [PubMed]

100. Weston, M.; Mazur, F.; Chandrawati, R. Monitoring of Food Spoilage Using Polydiacetylene- and Liposome-Based Sensors. In Smart Sensors for Environmental and Medical Applications; Wiley: Hoboken, NJ, USA, 2020; pp. 81-102. 
101. Valdez, M.; Gupta, S.K.; Lozano, K.; Mao, Y. ForceSpun polydiacetylene nanofibers as colorimetric sensor for food spoilage detection. Sens. Actuators B Chem. 2019, 297, 126734. [CrossRef]

102. Sudalaimani, S.; Esokkiya, A.; Hansda, S.; Suresh, C.; Tamilarasan, P.; Giribabu, K. Colorimetric Sensing of Putrescine and Cadaverine Using Ninhydrin as a Food Spoilage Detection Reagent. Food Anal. Methods 2020, 13, 629-636. [CrossRef]

103. Lova, P.; Comoretto, D. Label-free vapor selectivity by polymer-inorganic composite photonic crystals sensors. AIP Conf. Proc. 2018, 1981, 020097. [CrossRef]

104. Kuswandi, B.; Jayus; Restyana, A.; Abdullah, A.; Heng, L.Y.; Ahmad, M. A novel colorimetric food package label for fish spoilage based on polyaniline film. Food Control 2012, 25, 184-189. [CrossRef]

105. Morsy, M.K.; Zór, K.; Kostesha, N.; Alstrøm, T.S.; Heiskanen, A.; El-Tanahi, H.; Sharoba, A.; Papkovsky, D.; Larsen, J.; Khalaf, H.; et al. Development and validation of a colorimetric sensor array for fish spoilage monitoring. Food Control 2016, 60, 346-352. [CrossRef]

106. Machado, I.; Silva, L.R.; Giaouris, E.D.; Melo, L.F.; Simões, M. Quorum sensing in food spoilage and natural-based strategies for its inhibition. Food Res. Int. 2020, 127, 108754. [CrossRef] [PubMed]

107. Mohammadi, Z.; Jafari, S.M. Detection of food spoilage and adulteration by novel nanomaterial-based sensors. Adv. Colloid Interface Sci. 2020, 286, 102297. [CrossRef] [PubMed]

108. Blana, V.A.; Lianou, A.; Nychas, G.-J.E. Quorum sensing and microbial ecology of foods. In Quantitative Microbiology in Food Processing; John Wiley \& Sons, Ltd.: Chichester, UK, 2016; pp. 600-616.

109. Mishra, G.; Barfidokht, A.; Tehrani, F.; Mishra, R. Food Safety Analysis Using Electrochemical Biosensors. Foods $2018,7,141$. [CrossRef] [PubMed]

110. Mustafa, F.; Andreescu, S. Nanotechnology-based approaches for food sensing and packaging applications. RSC Adv. 2020, 10, 19309-19336. [CrossRef]

111. Zhai, X.; Zou, X.; Shi, J.; Huang, X.; Sun, Z.; Li, Z.; Sun, Y.; Li, Y.; Wang, X.; Holmes, M.; et al. Amine-responsive bilayer films with improved illumination stability and electrochemical writing property for visual monitoring of meat spoilage. Sens. Actuators $B$ Chem. 2020, 302, 127130. [CrossRef]

112. Wojnowski, W.; Majchrzak, T.; Dymerski, T.; Gębicki, J.; Namieśnik, J. Portable Electronic Nose Based on Electrochemical Sensors for Food Quality Assessment. Sensors 2017, 17, 2715. [CrossRef]

113. Bhadra, S.; Narvaez, C.; Thomson, D.J.; Bridges, G.E. Non-destructive detection of fish spoilage using a wireless basic volatile sensor. Talanta 2015, 134, 718-723. [CrossRef]

114. Chen, H.Z.; Zhang, M.; Bhandari, B.; Yang, C.H. Development of a novel colorimetric food package label for monitoring lean pork freshness. LWT 2019, 99, 43-49. [CrossRef]

115. Ghaani, M.; Cozzolino, C.A.; Castelli, G.; Farris, S. An overview of the intelligent packaging technologies in the food sector. Trends Food Sci. Technol. 2016, 51, 1-11. [CrossRef]

116. Liu, C.; Gao, G.; Zhang, Y.; Wang, L.; Wang, J.; Song, Y. The Naked-Eye Detection of NH3-HCl by Polyaniline-Infiltrated TiO2 Inverse Opal Photonic Crystals. Macromol. Rapid Commun. 2012, 33, 380-385. [CrossRef] [PubMed]

117. Ren, W.; Qin, M.; Hu, X.; Li, F.; Wang, Y.; Huang, Y.; Su, M.; Li, W.; Qian, X.; Tang, K.L.; et al. Bioinspired Synergy Sensor Chip of Photonic Crystals-Graphene Oxide for Multiamines Recognition. Anal. Chem. 2018, 90, 6371-6375. [CrossRef] [PubMed]

118. Han, S.; Jin, Y.; Su, L.; Chu, H.; Zhang, W. A two-dimensional molecularly imprinted photonic crystal sensor for highly efficient tetracycline detection. Anal. Methods 2020, 12, 1374-1379. [CrossRef]

119. Galstyan, V.; Bhandari, M.; Sberveglieri, V.; Sberveglieri, G.; Comini, E. Metal Oxide Nanostructures in Food Applications: Quality Control and Packaging. Chemosensors 2018, 6, 16. [CrossRef]

120. Choi, J.; Chen, Y.; Abbel, R.; Visagie, I.; Parker, K. Flexible humidity sensors for wireless monitoring based on electrospun sulfonated polyether ether ketone (SPEEK) nanofibres. Sens. Actuators B Chem. 2020, 324, 128704. [CrossRef]

121. Jiang, X.; Valdeperez, D.; Nazarenus, M.; Wang, Z.; Stellacci, F.; Parak, W.J.; del Pino, P. Future Perspectives Towards the Use of Nanomaterials for Smart Food Packaging and Quality Control. Part. Part. Syst. Charact. 2015, 32, 408-416. [CrossRef]

122. He, H.; Fu, Y.; Liu, S.; Cui, J.; Xu, W. Research progress and application of flexible humidity sensors for smart packaging: A review. In Proceedings of the Lecture Notes in Electrical Engineering; Springer: Berlin/Heidelberg, Germany, 2020; Volume 600, pp. 429-435.

123. Tan, E.L.; Ng, W.N.; Shao, R.; Pereles, B.D.; Ong, K.G. A wireless, passive sensor for quantifying packaged food quality. Sensors 2007, 7, 1747-1756. [CrossRef] [PubMed]

124. Uematsu, M.; Frank, E.U. Static Dielectric Constant of Water and Steam. J. Phys. Chem. Ref. Data 1980, 9, 1291-1306. [CrossRef]

125. Amin, Y.; Chen, Q.; Zheng, L.R.; Tenhunen, H. “Green” wideband log-spiral antenna for RFID sensing and wireless applications. J. Electromagn. Waves Appl. 2012, 26, 2043-2050. [CrossRef]

126. Deng, F.; He, Y.; Li, B.; Song, Y.; Wu, X. Design of a slotted chipless RFID humidity sensor tag. Sens. Actuators B Chem. 2018, 264, 255-262. [CrossRef]

127. Vena, A.; Perret, E.; Kaddour, D.; Baron, T. Toward a reliable chipless RFID humidity sensor tag based on silicon nanowires. IEEE Trans. Microw. Theory Tech. 2016, 64, 2977-2985. [CrossRef]

128. Borgese, M.; Dicandia, F.A.; Costa, F.; Genovesi, S.; Manara, G. An Inkjet Printed Chipless RFID Sensor for Wireless Humidity Monitoring. IEEE Sens. J. 2017, 17, 4699-4707. [CrossRef]

129. Sipilä, E.; Virkki, J.; Sydänheimo, L.; Ukkonen, L. Experimental study on brush-painted passive RFID-based humidity sensors embedded into plywood structures. Int. J. Antennas Propag. 2016, 2016. [CrossRef] 
130. Pichorim, S.F.; Gomes, N.J.; Batchelor, J.C. Two solutions of soil moisture sensing with rfid for landslide monitoring. Sensors 2018, 18, 452. [CrossRef] [PubMed]

131. Burratti, L.; De Matteis, F.; Casalboni, M.; Francini, R.; Pizzoferrato, R.; Prosposito, P. Polystyrene photonic crystals as optical sensors for volatile organic compounds. Mater. Chem. Phys. 2018, 212, 274-281. [CrossRef]

132. Potyrailo, R.A.; Bonam, R.K.; Hartley, J.G.; Starkey, T.A.; Vukusic, P.; Vasudev, M.; Bunning, T.; Naik, R.R.; Tang, Z.; Palacios, M.A.; et al. Towards outperforming conventional sensor arrays with fabricated individual photonic vapour sensors inspired by Morpho butterflies. Nat. Commun. 2015, 6, 1-12. [CrossRef]

133. Yang, H.; Pan, L.; Han, Y.; Ma, L.; Li, Y.; Xu, H.; Zhao, J. A visual water vapor photonic crystal sensor with PVA/SiO 2 opal structure. Appl. Surf. Sci. 2017, 423, 421-425. [CrossRef]

134. Sobhanimatin, M.B.; Pourmahdian, S.; Tehranchi, M.M. Colorimetric Monitoring of Humidity by Opal Photonic Hydrogel. Polym. Test. 2020, 106999. [CrossRef]

135. Ndraha, N.; Hsiao, H.I.; Vlajic, J.; Yang, M.F.; Lin, H.T.V. Time-temperature abuse in the food cold chain: Review of issues, challenges, and recommendations. Food Control 2018, 89, 12-21. [CrossRef]

136. Göransson, M.; Nilsson, F.; Jevinger, A. Temperature performance and food shelf-life accuracy in cold food supply chainsInsights from multiple field studies. Food Control 2018, 86, 332-341. [CrossRef]

137. Cruz, R.M.S.; Alves, V.; Khmelinskii, I.; Vieira, M.C. New Food Packaging Systems. In Food Packaging and Preservation; Elsevier: Amsterdam, The Netherlands, 2018; pp. 63-85.

138. Mijanur Rahman, A.; Kim, D.; Jang, H.; Yang, J.; Lee, S. Preliminary Study on Biosensor-Type Time-Temperature Integrator for Intelligent Food Packaging. Sensors 2018, 18, 1949. [CrossRef]

139. Hsiao, H.-I.; Chang, J.-N. Developing a microbial time-temperature indicator to monitor total volatile basic nitrogen change in chilled vacuum-packed grouper fillets. J. Food Process. Preserv. 2017, 41, e13158. [CrossRef]

140. Tsironi, T.; Stamatiou, A.; Giannoglou, M.; Velliou, E.; Taoukis, P.S. Predictive modelling and selection of Time Temperature Integrators for monitoring the shelf life of modified atmosphere packed gilthead seabream fillets. LWT-Food Sci. Technol. 2011, 44, 1156-1163. [CrossRef]

141. Nuin, M.; Alfaro, B.; Cruz, Z.; Argarate, N.; George, S.; Le Marc, Y.; Olley, J.; Pin, C. Modelling spoilage of fresh turbot and evaluation of a time-temperature integrator (TTI) label under fluctuating temperature. Int. J. Food Microbiol. 2008, 127, 193-199. [CrossRef] [PubMed]

142. Ayyanar, N.; Vasantha Jayakantha Raja, R.; Vigneswaran, D.; Lakshmi, B.; Sumathi, M.; Porsezian, K. Highly efficient compact temperature sensor using liquid infiltrated asymmetric dual elliptical core photonic crystal fiber. Opt. Mater. (Amst). 2017, 64, 574-582. [CrossRef]

143. De, M.; Gangopadhyay, T.K.; Singh, V.K. Prospects of Photonic Crystal Fiber as Physical Sensor: An Overview. Sensors 2019, 19, 464. [CrossRef]

144. Li, J.X.; Tong, Z.R.; Jing, L.; Zhang, W.H.; Qin, J.; Liu, J. wei Fiber temperature and humidity sensor based on photonic crystal fiber coated with graphene oxide. Opt. Commun. 2020, 467, 125707. [CrossRef]

145. TTI Label > Vitsab International AB. Available online: http://vitsab.com/en/tti-label/ (accessed on 6 March 2021).

146. Timestrip Plus I Timestrip. Available online: https://timestrip.com/products/timestrip-plus/\#tech (accessed on 6 March 2021).

147. Wang, S.; Liu, X.; Yang, M.; Zhang, Y.; Xiang, K.; Tang, R. Review of Time Temperature Indicators as Quality Monitors in Food Packaging. Packag. Technol. Sci. 2015, 28, 839-867. [CrossRef]

148. Pennanen, K.; Focas, C.; Kumpusalo-Sanna, V.; Keskitalo-Vuokko, K.; Matullat, I.; Ellouze, M.; Pentikäinen, S.; Smolander, M.; Korhonen, V.; Ollila, M. European Consumers' Perceptions of Time-Temperature Indicators in Food Packaging. Packag. Technol. Sci. 2015, 28, 303-323. [CrossRef]

149. Choi, D.Y.; Jung, S.W.; Lee, D.S.; Lee, S.J. Fabrication and Characteristics of Microbial Time Temperature Indicators from Bio-Paste Using Screen Printing Method. Packag. Technol. Sci. 2014, 27, 303-312. [CrossRef]

150. Kreyenschmidt, J.; Christiansen, H.; Hübner, A.; Raab, V.; Petersen, B. A novel photochromic time-temperature indicator to support cold chain management. Int. J. Food Sci. Technol. 2010, 45, 208-215. [CrossRef]

151. Mohebi, E.; Marquez, L. Intelligent packaging in meat industry: An overview of existing solutions. J. Food Sci. Technol. 2015, 52, 3947-3964. [CrossRef]

152. Sadilek, A.; Caty, S.; DiPrete, L.; Mansour, R.; Schenk, T.; Bergtholdt, M.; Jha, A.; Ramaswami, P.; Gabrilovich, E. Machine-learned epidemiology: Real-time detection of foodborne illness at scale. NPJ Digit. Med. 2018, 1, 36. [CrossRef] [PubMed]

153. Legese, M.H.; Weldearegay, G.M.; Asrat, D. Extended-spectrum beta-lactamase- and carbapenemase-producing Enterobacteriaceae among ethiopian children. Infect. Drug Resist. 2017, 10, 27-34. [CrossRef]

154. Gupta, V.; Gulati, P.; Bhagat, N.; Dhar, M.S.; Virdi, J.S. Detection of Yersinia enterocolitica in food: An overview. Eur. J. Clin. Microbiol. Infect. Dis. 2015, 34, 641-650. [CrossRef] [PubMed]

155. Safenkova, I.V.; Zaitsev, I.A.; Varitsev, Y.A.; Byzova, N.A.; Drenova, N.V.; Zherdev, A.V.; Dzantiev, B.B. Development of a lateral flow immunoassay for rapid diagnosis of potato blackleg caused by Dickeya species. Anal. Bioanal. Chem. 2017, 409, 1915-1927. [CrossRef] [PubMed]

156. Gokduman, K.; Dilek Avsaroglu, M.; Cakiris, A.; Ustek, D.; Candan Gurakan, G. Recombinant plasmid-based quantitative Real-Time PCR analysis of Salmonella enterica serotypes and its application to milk samples. J. Microbiol. Methods 2016, 122, 50-58. [CrossRef] 
157. Yang, X.; Tang, Y.; Alt, R.R.; Xie, X.; Li, F. Emerging techniques for ultrasensitive protein analysis. Analyst 2016, 141 , 3473-3481. [CrossRef] [PubMed]

158. Ramos, A.C.; Gales, A.C.; Monteiro, J.; Silbert, S.; Chagas-Neto, T.; Machado, A.M.O.; Carvalhaes, C.G. Evaluation of a rapid immunochromatographic test for detection of distinct variants of Klebsiella pneumoniae carbapenemase (KPC) in Enterobacteriaceae. J. Microbiol. Methods 2017, 142, 1-3. [CrossRef] [PubMed]

159. Tominaga, T. Enhanced sensitivity of lateral-flow test strip immunoassays using colloidal palladium nanoparticles and horseradish peroxidase. LWT-Food Sci. Technol. 2017, 86, 566-570. [CrossRef]

160. Tominaga, T. Rapid detection of Klebsiella pneumoniae, Klebsiella oxytoca, Raoultella ornithinolytica and other related bacteria in food by lateral-flow test strip immunoassays. J. Microbiol. Methods 2018, 147, 43-49. [CrossRef] [PubMed]

161. Foudeh, A.M.; Fatanat Didar, T.; Veres, T.; Tabrizian, M. Microfluidic designs and techniques using lab-on-a-chip devices for pathogen detection for point-of-care diagnostics. Lab Chip 2012, 12, 3249-3266. [CrossRef]

162. Yousefi, H.; Su, H.-M.; Ali, M.; Filipe, C.D.M.; Didar, T.F. Producing Covalent Microarrays of Amine-Conjugated DNA Probes on Various Functional Surfaces to Create Stable and Reliable Biosensors. Adv. Mater. Interfaces 2018, 5, 1800659. [CrossRef]

163. Tokel, O.; Yildiz, U.H.; Inci, F.; Durmus, N.G.; Ekiz, O.O.; Turker, B.; Cetin, C.; Rao, S.; Sridhar, K.; Natarajan, N.; et al. Portable Microfluidic Integrated Plasmonic Platform for Pathogen Detection. Sci. Rep. 2015, 5. [CrossRef]

164. Altintas, Z.; Akgun, M.; Kokturk, G.; Uludag, Y. A fully automated microfluidic-based electrochemical sensor for real-time bacteria detection. Biosens. Bioelectron. 2018, 100, 541-548. [CrossRef]

165. Basu, P.K.; Indukuri, D.; Keshavan, S.; Navratna, V.; Vanjari, S.R.K.; Raghavan, S.; Bhat, N. Graphene based E. coli sensor on flexible acetate sheet. Sens. Actuators B Chem. 2014, 190, 342-347. [CrossRef]

166. DuVall, J.A.; Borba, J.C.; Shafagati, N.; Luzader, D.; Shukla, N.; Li, J.; Kehn-Hall, K.; Kendall, M.M.; Feldman, S.H.; Landers, J.P. Optical imaging of paramagnetic bead-DNA aggregation inhibition allows for low copy number detection of infectious pathogens. PLOS ONE 2015, 10. [CrossRef]

167. Loutfi, H.; Pellen, F.; Le Jeune, B.; Lteif, R.; Kallassy, M.; Le Brun, G.; Abboud, M. Real-time monitoring of bacterial growth kinetics in suspensions using laser speckle imaging. Sci. Rep. 2020, 10, 1-10. [CrossRef] [PubMed]

168. Liu, Z.; Ebrahimi, A.; Zhou, K.; Zhou, C.; Sapre, A.; Pavlock, J.H.; Weaver, A.; Muralidharan, R.; Noble, J.; Chung, T.; et al. Dynamic laser speckle imaging meets machine learning to enable rapid antibacterial susceptibility testing (DYRAST). ACS Sens. 2020, 5, 3140-3149. [CrossRef]

169. Urusov, A.E.; Zherdev, A.V.; Dzantiev, B.B. Towards Lateral Flow Quantitative Assays: Detection Approaches. Biosensors 2019, 9, 89. [CrossRef] [PubMed]

170. Bonifacio, L.D.; Puzzo, D.P.; Breslav, S.; Willey, B.M.; McGeer, A.; Ozin, G.A. Towards the Photonic Nose: A Novel Platform for Molecule and Bacteria Identification. Adv. Mater. 2010, 22, 1351-1354. [CrossRef] [PubMed]

171. Inan, H.; Poyraz, M.; Inci, F.; Lifson, M.A.; Baday, M.; Cunningham, B.T.; Demirci, U. Photonic crystals: Emerging biosensors and their promise for point-of-care applications. Chem. Soc. Rev. 2017, 46, 366-388. [CrossRef]

172. Paternò, G.M.; Moscardi, L.; Donini, S.; Ariodanti, D.; Kriegel, I.; Zani, M.; Parisini, E.; Scotognella, F.; Lanzani, G. Hybrid one-dimensional plasmonic-photonic crystals for optical detection of bacterial contaminants. J. Phys. Chem. Lett. 2019, 10, 4980-4986. [CrossRef]

173. Paternò, G.M.; Moscardi, L.; Donini, S.; Ross, A.M.; Pietralunga, S.M.; Dalla Vedova, N.; Normani, S.; Kriegel, I.; Lanzani, G.; Scotognella, F. Integration of bio-responsive silver in 1D photonic crystals: Towards the colorimetric detection of bacteria. Faraday Discuss. 2020, 223, 125-135. [CrossRef] [PubMed]

174. Painam, B.; Kaler, R.S.; Kumar, M. On-Chip Oval-Shaped Nanocavity Photonic Crystal Waveguide Biosensor for Detection of Foodborne Pathogens. Plasmonics 2018, 13, 445-449. [CrossRef]

175. Li, S.; Huang, J.; Cai, L. A porous silicon optical microcavity for sensitive bacteria detection. Nanotechnology 2011, 22. [CrossRef]

176. Lova, P.; Megahd, H.; Stagnaro, P.; Alloisio, M.; Patrini, M.; Comoretto, D. Strategies for Dielectric Contrast Enhancement in 1D Planar Polymeric Photonic Crystals. Appl. Sci. 2020, 10, 4122. [CrossRef]

177. Smart Packaging Market I Growth, Trends, and Forecast (2020-2025). Available online: https://www.mordorintelligence.com/ industry-reports/smart-packaging-market (accessed on 19 February 2021).

178. Zhao, L.; Duan, G.; Zhang, G.; Yang, H.; He, S.; Jiang, S. Electrospun Functional Materials toward Food Packaging Applications: A Review. Nanomaterials 2020, 10, 150. [CrossRef] [PubMed]

179. Joardder, M.U.H.; Hasan Masud, M.; Joardder, M.U.H.; Masud, M.H. Challenges and Mistakes in Food Preservation. In Food Preservation in Developing Countries: Challenges and Solutions; Springer International Publishing: Cham, Switzerland, 2019; pp. 175-198.

180. Enescu, D.; Cerqueira, M.A.; Fucinos, P.; Pastrana, L.M. Recent advances and challenges on applications of nanotechnology in food packaging. A literature review. Food Chem. Toxicol. 2019, 134, 110814. [CrossRef]

181. Landaluce, H.; Arjona, L.; Perallos, A.; Falcone, F.; Angulo, I.; Muralter, F. A Review of IoT Sensing Applications and Challenges Using RFID and Wireless Sensor Networks. Sensors 2020, 20, 2495. [CrossRef]

182. Bibi, F.; Guillaume, C.; Gontard, N.; Sorli, B. A review: RFID technology having sensing aptitudes for food industry and their contribution to tracking and monitoring of food products. Trends Food Sci. Technol. 2017, 62, 91-103. [CrossRef]

183. Mondal, S.; Wijewardena, K.P.; Karuppuswami, S.; Kriti, N.; Kumar, D.; Chahal, P. Blockchain inspired RFID-based information architecture for food supply chain. IEEE Internet Things J. 2019, 6, 5803-5813. [CrossRef] 
184. Alfian, G.; Rhee, J.; Ahn, H.; Lee, J.; Farooq, U.; Ijaz, M.F.; Syaekhoni, M.A. Integration of RFID, wireless sensor networks, and data mining in an e-pedigree food traceability system. J. Food Eng. 2017, 212, 65-75. [CrossRef]

185. Maddipatla, D.; Narakathu, B.B.; Atashbar, M. Recent Progress in Manufacturing Techniques of Printed and Flexible Sensors: A Review. Biosensors 2020, 10, 199. [CrossRef]

186. Rivadeneyra, A.; López-Villanueva, J.A. Recent Advances in Printed Capacitive Sensors. Micromachines 2020, 11, 367. [CrossRef]

187. Adeyeye, S.A.O. Food packaging and nanotechnology: Safeguarding consumer health and safety. Nutr. Food Sci. 2019, 49, 1164-1179. [CrossRef]

188. Sothornvit, R. Nanostructured materials for food packaging systems: New functional properties. Curr. Opin. Food Sci. 2019, 25, 82-87. [CrossRef]

189. Meherishi, L.; Narayana, S.A.; Ranjani, K.S. Sustainable packaging for supply chain management in the circular economy: A review. J. Clean. Prod. 2019, 237, 117582. [CrossRef]

190. Boz, Z.; Korhonen, V.; Koelsch Sand, C. Consumer Considerations for the Implementation of Sustainable Packaging: A Review. Sustainability 2020, 12, 2192. [CrossRef]

191. Abhijith, R.; Ashok, A.; Rejeesh, C.R. Sustainable packaging applications from mycelium to substitute polystyrene: A review. Mater. Today Proc. 2018, 5, 2139-2145. [CrossRef]

192. Dodero, A.; Schlatter, G.; Hébraud, A.; Vicini, S.; Castellano, M. Polymer-free cyclodextrin and natural polymer-cyclodextrin electrospun nanofibers: A comprehensive review on current applications and future perspectives. Carbohydr. Polym. 2021, 264, 118042. [CrossRef]

193. Aramyan, L.; Grainger, M.; Logatcheva, K.; Piras, S.; Setti, M.; Stewart, G.; Vittuari, M. Food waste reduction in supply chains through innovations: A review. Meas. Bus. Excell. 2020. [CrossRef] 